\title{
REPRESENTATION BY TERRITORY: \\ A Proposal for Senate Reform
}

\section{Bruce Pardy}

This article introduces an idea about $\mathrm{S}$ enate reform that politicians in no part of $\mathrm{C}$ anada w ill like. It would reduce the political power of Ontario. It would fall short of Quebec federalist aspirations. It would not give the Western provinces a Triple-E Senate. It would diminish the status of the Atlantic provinces as a region of Canada equal to the others. It would not grant provincial status to the Territories. In spite of all this, or perhaps because of it, the idea makes some sense.

Reform of the Canadian Senate has been discussed for many years. Many proposals have been developed. ${ }^{1}$ It has been the subject of many learned papers by distinguished authors, including artic les in this journa $1{ }^{2}$

\footnotetext{
For example, see P. McCormick, E. Manning and G. Gibson, Regional Representation: The Canadian Partne rship (Calgary: Canad a Wes t Foundation, 1981); Canada, Report of the Special Joint Committee of the Senate and of the House of Commons on Senate Reform (Ottawa: Queen 's Printer, 1984) ["M olgat-Cosgrove"]; Canada, Report of the Royal Commission on the Econo mic Union and Developmen t Prospects for Canada, Volume III (Ottawa: Minister of Supply and Services Canada, 1985) ["Macdonald"]; Report of the Alberta Special Select Committee on Senate Reform, Strengthening Canada: Reform of Canada's Senate (Edmonton: Gove rnment of Alberta, 1985) ["Alb erta"]; Canada, A Renewed Canada: Report of the Special Joint Committee of the Senate and of the House of Commons (Ottawa: Queen's Printer, 1992) ["Beaudoin-Dobbie"]; and Consensus Report on the Constitution, s.8, Charlottetown, 28 August 1992 and Draft Legaltext, s.4, 9 Octobe $r 1992$ ["C harlottetown"].

For example, see R. Watts, "The Reform of Federal Institutions" in K. M cRob erts and P. Mon ahan, eds., The CharlottetownAccord, the Referendum, and the Future of Canada,(Toronto: University of Toronto, 1993) 1; R. Janda, Re-balancing the Federation through Senate Reform: Another Look at the Bundesrat, Study No. 11 of the York U niversity C onstituti onal Reform Pro ject (North York: York University Centre for Public L aw and Public Policy, 1992); G. Laxer, "Distinct Statu s for Qu ebec: A Benefit to English Canada" (1992), 3 Constitutional Forum 57; I. Urquhart, "On S enate R eform" (1992), 3 Constitutional Forum 67; C. M assey, "Devolution or Disunion: The Constitution After Meech Lake" (1991), 29
}

It is difficult to find a formula which satisfies parties with different and, in some cases, conflicting complain ts about representation within the Canadian federation. One way to proceed with an enterprise like Senate reform is to identify a dem ocratic principle on which to build the institution, rather than jumping to arbitrary combinations designed to appease unhappy constituencies in various parts of the country. This article discusses representation in a reformed Senate based upon such a principle. It would produce a more balanced distribution of power in the Canadian Parliament.

Proposa ls for Senate reform typically address three issues: distribution of seats, method of selection, and powers. This proposal addresses primarily the distribution of seats. It also affects the question of selection: it requires that senators be elected on a constituency basis, as described below. However, the proposal does not explore the detail of such elections, such as form or frequency. The question of powers of a reformed Senate are generally beyond the scope of this proposal. However, it is an essential element of the proposal that the reformed Senate be "effective" in Triple-E terms, and some brief remarks about pow ers appear later in the piece.

\section{The SenATE'S PuRPose: COUNTERBALANCING REPRESENTATION BY POPULATION}

Representation by population is usually considered to be the most appropriate democratic mechanism because it most closely reflects the democratic ideal of equality of political influence - one person, one vote.

Osgoode Hall LJ. 791; M. Crommelin, "Senate Reform: Is the Game Worth the Candle?" (1989), 23 U.B.C.L.R. 197; C. Franks, "The Senate and Its Reform" (1987), 12 Queen's L.J. 455. 
It need be qualified only where there are circumstances in which it crea tes disproportionate influence for some areas of the country over the national agenda.

Canada is such a place. The uneven distribution of its population means that certain areas of the country are more heavily represented than others. The Western provinces have long complained that the concentration of seats held by Ontario and Quebec in the House of Commons concentrates the government's focus and concern on those parts of the country.

One of the purposes of a second legislative chamber like a senate is to counterbalance such effects. This is accomplished by constituting the second chamber on some basis other than representation by population. The Senate was originally established on the basis of regional representation, with 24 seats allocated to each of three regions. ${ }^{3}$ The Western provinces later became a fourth region. ${ }^{4}$ Six seats were allocated to Newfoundland when it joined Confederation in $1949,{ }^{5}$ and one was given to both of the Territories in $1975 .{ }^{6}$ These later additions threw off the purity of the distribution, but no new basis for representation in the Senate was introduced.

\section{PreVious PROPOSALS}

This essay discusses a new basis for distributing seats in the Senate. The other options that have been proposed are: representation by region; representation by province; representation by region or province adjusted for population differences; and arbitrary distributions based on what might be politically and democra tically acceptab le. Promine nt reform proposals of the past 15 years have distributed seats in each of these ways. See the table on the following page for a comparis on of proposals.

When distribution is based upon representation by province, two things happen: the Atlantic provinces, small in population and territory, get as many seats as the provinces of the $\mathrm{W}$ est; and they get twice as many seats as Ontario and Quebec combined. The first has the effect of frustrating Western ambitions for a more significantrole in a federal legislative body, ${ }^{7}$ the second makes it politically and democratically necessary to diminish the Senate's powers.

When distribution is based upon representation by region, Ontario and Quebec are usually counted as regions on their ow $n$. British Columbia has argued that it also should constitute a region. ${ }^{8}$ If any or all of these three provinces were to be granted regional status, as is the case in the present Senate for Quebec and Ontario, the purpose of counterbalancing representation by population in the House of Commons would be compro mised: sud denly pop ulation would become the basis for regional representation, and there would seem to be little in point in having an upper House at all. Indeed, the same can be said for any allocation based on population distribution.

\section{Proposal for a Reformed Senate: REPRESENTATION BY TERRITORY}

In simple terms, a country consists of its people and its territory. Sovereignty means the exclusive ability to make and enforcelaws within a physicalarea. The House of Commons is based upon representation by population; the Senate should be based upon representation by territory. Each senator would be elected by the residents within an area of land of common size, say, for the sake of argument, 50,000 square kilometres.

The original section 22 of the Constitution Act, 1867, 30 \& 31 Victoria, c. 3 (U.K.), provided for three "divisions": Ontario, Quebec, and the Maritime Provinces, Nova Scotia and New Brunswick, and gave 24 seats to Ontario, 24 to Quebec, and 12 to both of Nova Scotia and New Brunswick. See P. Hogg, Constitutional Law of Canada 3rd ed. (Toro nto: Carsw ell, 1992) s. 5.1(f).

4 By 1915 , the 24 seats per region structure had been reproduced with 6 seats for each of the Western provinces, 10 for both of Nova Scotia and New Brunswick, and 4 for P.E.I.: Constitution Act, 1915, 5-6 Geo. V, c. 45 (U.K.).

$5 \quad$ Newfoundland Act, 12-13 Ge o. VI, c. 22 (U.K.).

6 Constitution Act (No. 2), 1975, S.C. 1974-75-76, c.53. In the Albertaversion of the Triple-E Senate, the West
receives $37.5 \%$ of Senate seats, while in Molgat-
Cosgrove, itreceives $33.3 \%$, a difference of only $4.2 \%$.
Senate reform advocated by B ritish Columbia in 1978
was based on equal regional representation for five
distinct regions, Atlantic, Quebec, Ontario, Prairie, and
B.C. See British Columbia's Constitutional Proposals,
Paper No. 3: Reform of the Canadian Senate (Victoria:
Province of B.C., 1978) at 18-19. 


\section{Areas}

The geographical areas of the provinces in square kilometres, and as a percentage of the total area of the provinces combined:

\begin{tabular}{lrrrr} 
& \multicolumn{2}{c}{ without Labrador } & \multicolumn{2}{c}{ with Labrador } \\
Nfld & 111,390 & $1.9 \%$ & 405,720 & $6.6 \%$ \\
PEI & 5,660 & $0.1 \%$ & & $0.1 \%$ \\
NS & 55,490 & $1.0 \%$ & & $0.9 \%$ \\
NB & 73,440 & $1.3 \%$ & & $1.2 \%$ \\
Que & $1,540,680$ & $26.7 \%$ & & $25.4 \%$ \\
Ont & $1,068,580$ & $18.5 \%$ & & $17.6 \%$ \\
Man & 649,950 & $11.3 \%$ & & $10.7 \%$ \\
Sask & 652,330 & $11.3 \%$ & & $10.8 \%$ \\
Alta & 661,190 & $11.4 \%$ & & $10.9 \%$ \\
BC & 947,800 & $16.4 \%$ & & $15.6 \%$ \\
TOTAL & $5,766,510$ & $99.9 \%$ & $6,060,840$ & $99.8 \%$
\end{tabular}

\section{SEATS}

Assuming one Senate seat for each 50,000 square kilometres, with a minimum of one seat per province, the distribution of seats would be:

Nfld

PEI

NS

NB

Que

Ont

Man

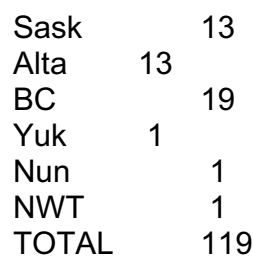




\section{Comparison of REPRESENTATION BY TERRITORY WITH Other Proposals ${ }^{*}$}

1. By Province

Current Senate
(1)

Representation by Territory

$\begin{array}{lll}\text { Nfld } & 6 & 3 \\ \text { PEI } & 4 & 1 \\ \text { NS } & 10 & 1 \\ \text { NB } & 10 & 1 \\ \text { Que } & 24 & 31 \\ \text { Ont } & 24 & 21 \\ \text { Man } & 6 & 13 \\ \text { Sask } & 6 & 13 \\ \text { Alta } & 6 & 13 \\ \text { BC } & 6 & 19 \\ \text { Yuk } & 1 & 1 \\ \text { Nun } & - & 1 \\ \text { NWT } & 1 & 1 \\ \text { TOTAL } & 104 & 119\end{array}$

(2)

MolgatCosgrove \& Macdonald

12
6
12
12
24
24
12
12
12
12
2
-
4
144

(3) Charlottetown Dobbie

6

6

6

6

\section{6}

6

6

6

6

6

$2 / 1$

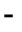

$2 / 1$

$64 / 62$

Alberta \& Charlottetown

Beaudoin-

MolgatCosgrove \& Macdonald

Atlantic $\quad 30 \quad 6$

Central

West

$$
48
$$

24

Territories

TOTAL

2

104
Representation by Territory

6

52

58

3

119
42

48

48

6

144
$7 / 6$

$4 / 4$

$10 / 8$

$10 / 8$

$30 / 20$

$30 / 20$

$12 / 8$

$12 / 8$

$18 / 12$

$18 / 12$

$1 / 1$

$2 / 2$

$154 / 109$

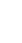

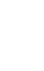

0

udoin- 
proposal. Nevertheless, Quebec federalists might find it worth supporting because it proposes to increase Quebec's national legislative influence in a manner which is sensible and legitimate: increased influence results from application of the same criteria being applied to all of the provinces.

Regionally, the West gains the most from this proposal. The provinces of Manitoba, Saskatchewan, Alberta and British Columbia ${ }^{9}$ together would control more seats than Ontario and Quebec combined, by virtue of their larger combined land mass. This share of seats would be significantly larger than what they control in the present Senate. It is also larger than what they would get in proposals based upon provincial equality, such as the Triple-E Senate, not to mention what they are allocated in proposals based upon something other than provincial equality. ${ }^{10}$ These se ats would not be designated to the 'Western Region' but to particular areas within the four provinces, with British Columbia holding almost as many seats as populous Ontario. Thus, the senators from these provinces would be able to vote as a bloc if they chose, but would represent particular areas of particular provinces.

When Senate reform is based upon representation by province or representation by region, the Atlantic provinces present problems. The Atlantic provinces are small in population and territory, but representation by province gives them as many seats as the provinces of the West; ${ }^{11}$ and twice as many as Ontario and Quebec combined. Representation by region produces similar problems. Granting the Atlantic provinces the status of a region means that they receive as many seats as the West, and that Ontario and Quebec need to be considered as separate regions. A S enate with seats representing land areas of equal size avoids these problems because the Atlantic provinces are comparatively small in size. Prince Edward Island is a

9 British Columbia has been included as a province of the West, rather than in its own category, because its status does not affect the proposal one way or the other. See A. McLellan, "The West: Myth or Reality in the Constitutional Reform Process?" (1992) 3 Constitutional Forum 88 at 90 .

10 The Western share of seats in a Senate built upon representation by territory is $48.7 \%$; in the present Senate $23.1 \%$; in the Alberta proposal, 37.5\%; in MolgatCosgrove, $33.3 \%$; in Beaudoin-Dobbie, $39.0 \%$ or $36.7 \%$. Representation by province is a better option for the West than representation by region: in the present Senate, not only do Qu ebec and Onta rio have as many seats each as the Western provinces have together, butNova Scotia and New Brunsw ick have m ore (10) than ea ch of the W estern provinces (6). Nevertheless, representation by province aids the A tlantic provinces far more than the West when measured in terms of population or territory. tiny 0.1 per cent of the total land mass of all the provinces combined, while New Brunswick and Nova Scotia are both close to 1 per cent. The Island of Newfoundland is almost 2 per cent. The province of Newfoundland is over 6 per cent if Labrador is included, but a case could be made that Labrador should be treated as a Territory (see below), given its minuscule population and econ omy.

\section{THE TERRITORIES}

The northern Territories pose the most significant obstacle to a Senate based on representation by territory. The geographical size of the Yukon, Nunavut ${ }^{12}$ and Northwest Territories is vastly out of proportion to their populations, economies and other measurements of significance within the Canadian federation. Together, the Territories contain approxim ately 3.9 million square kilometres, or almost 40 per cent of Canada's land mass. In contrast, as of early 1996 , only 97,000 people lived in the territories, about 0.3 per cent of the country's population, ${ }^{13}$ smaller than even the population of Prince Edward Island. If the Territories were given one Sen ate seat for each 50,000 square kilometres in accordan ce with this p roposal, they would obviously dominate the Senate and would make the proposal unworkable. Conveniently, the Territories are not provinces, and would have to be placed into a different category. In spite of the fact that their populations are so small, their size does justify a role in a Senate based upon representation by territory, and thus each of the three territories, Yukon, Nunavut and the Northwest Territories should be allocated a Senate seat.

\section{StRENGTHENING THE Centre}

Representation by population alone creates disproportio nate influence for some geographical areas over the national agenda. One effect of uneven population distribution in a system operating only on the basis of representation by population is the imposition of laws on areas of land (and on the residents in those areas) in the absence of any meaningful degree of political representation.

12 The territory of Nunavut is to be created out of the northern and eastern sections of the Northwest Territories on April 1, 1999 : Nunavut Act, S.C. 1993,c. 28, ss. 3 and 79. It will consist of approximately 2.2 million square kilometres, with a population of on ly 25,000: Canada Year Book 1997 (Ottaw a: Statistics Canada, 1996) 448449.

13 Canada Year Book 1997, ibid. at 4. 
In its present configuration, the Senate does not provide a counterbalance to the House of Commons. Senator voting follows party lines rather than provincial allegiances, and the appointed body rarely exercises the breadth of its formal legislative powers. ${ }^{14}$ Its existence does not dilute the disenfranchising effects of the distribution of the Can adian population. One result is continued calls for and granting of increased provincial powers. An unreformed Senate is part of the cause of the decentralization of Canada. An effectively reformed Senate could be a vehicle to revitalize the centre; it could serve as an alternative to ever increasing provincial powers. ${ }^{15}$

A Senate based upon representation by territory could prove to be more democratically representative than provincial governments. One common argument in favour of greater provincial powers is that the provincial governm ents are 'closer to the people' than the federal government, and are thus more responsible and responsive to the needs of the people they represent. This is not quite true: the distorting effects of population distribution oc cur within provinces as easily as within Canada. Certainly, greater provincial pow ers give greater political influence to voters residing in Vancouve $r$, but hardly to voters residing in Atlin, B.C. It makes little difference whether the fate of areas in northern B.C. is decided by a legislature dominated by Vancouver or one dominated by Vancouver, Toronto and other large po pulation cen tres. Urban dwellers in Vancouver have far more in common with residents of Calgary or Toronto th an they do with residents of Atlin, just as residents of Toronto have more in comm on with the residents of Vancouver than they do with people living in Bruce Mines, Ontario. The divergence in interests of the people has more to do with the land they occupy, its location, population density, characteristics and uses, than with the province that that land happens to be located within. Representation by physical territory in the Senate w ould give the residents of Atlin and Bruce Mines more significant political representation than shifting greater powers to the provincial level.

\section{Powers of the Reformed Senate}

Previous proposals for Senate reform have described a variety of combinations of Senate powers. ${ }^{16}$

14 Hogg, Constitutional Law of Canada, supra note 3 at s. 9.4(c).

Hog g, ibid. at s. 4.8(c).

16 For a concise review of Senate powers in Senate reform proposals, see J. Stillborn, Senate Reform Proposals in Comparative Perspective (Ottawa: Library of Parliament
The principle of representation by territory does not touch on this question, other than requiring that the Senate have sufficient powers to fulfil its purpose. The purpose of a Senate built upon the principle of representation by territory is to counterbalance disproportio nate influence created by representation by population in the House of Commons. If the reformed Senate is to fulfil this purpose, it must have powers sufficient to function as a genuine political and legislative force comparable to the House of Commons. In Triple-E parlance, it must be "effective." Ind eed, if the Senate was built upon a sound democratic principle, it could be allowed to be effective; it would pose no threat to representative and responsible government. One possibility would be to have the Senate keep the powers that it presently has but rarely exercises: Under the Constitution Act, 1867, the Senate has the same powers as the House of Commons, with the exception that money bills must originate in the House of Commons. ${ }^{17}$

\section{REQUIREMENTS FOR COMPOSITION OF AN UPPER CHAMBER}

If the Senate is to exist at all, it should be constituted in a way which is not arbitrary, but based on objective criteria. Furthermo re, it should be constituted in a way which ameliorates the constitutional grievances expressed by Quebec and the Western provinces.

Creating an upper chamber which in itself would completely satisfy these different constituencies seems unlikely. Their aspirations are based upon conflicting conceptions of the country. The theory propounded by Quebec is that Canada is fundamentally a land of two founding peoples, English and French. The view heard from the West is that Canada is a federation of ten equal provinces, none more or less important than any other.

Not surprisingly, the aspirations expressed by Quebec and the Western provinces about future constitutional arrangements reflect these conceptions. For example, in 1985 the Liberal govemment of Quebec described five conditions for Quebec's acceptance of the Constitution Act, 1982: (1) recognition of Quebec as a distinct society; (2) a greater role in immigration; (3) a provincial role in Supreme Court of Canada appointments; (4) limitations on the federal

Research B ranch, 1992).

17 Section 53. Se e Hogg, Constitutional Law of Canada, supra note 3 at s. 9.4(c). 
spending power; and (5) a Quebec veto on constitutional amendments. ${ }^{18}$ These are logicalrequests if one begins with the presumption that the English and French make up the two dominant and identifiable partners in the Canadian federation.

From the Western perspective, because the House of Commons is based upon representation by population and because the populations of Ontario and Quebec are considerably larger than the population of the Western provinces, the focus of the nation's business as conducted in the House of Commons tends to be east of the Manitoba-Ontario border. Senate reform has been one of the West's preferred methods of correcting this imbalance. ${ }^{19}$ The $\mathrm{W}$ estern prop osal is the Triple-E Senate: equal, elected and effective. Such a Senate would properly reflect the West's conception of Canada as a federation of ten equal parts - "equal" meaning that each province would have an equal number of seats in the upper House.

Neither one of these propositions is acceptable, certainly not from the perspective of the other, and perhaps not in Ontario, which has the most to lose from a Triple-E Senate and greater Qu ebec pow ers. Both se ts of proposals are based upon visions of the federation not shared across the country, rather than upon a sound alternative basis of proportional representation.

Therefore, what is required is a Senate which gives a greater voice to both Quebec and the West, on some basis which does not adopt either's theory of confederation, and which is sufficiently logical and objective to cause Ontario to agree to a decrease in influence. In other words, a future Senate, if it is to wholly or partially solve Canada's constitutional difficulties, must: (1) increase Quebec's influence; (2) increase the influence of the Western provinces, individually and as a group; and (3) make sense. It must be based on a democratic principle beyond mere accommodation of grieving regions, and be more than a larger share of seats for Quebec and the West. A Senate based upon the principle of representation by territory satisfies all thre e requirem ents.

18 P. Hog g, Is the Canadian Constitution Ready for the 21 st Century? Study No. 1 of the York University Constitutional Reform Project (North York: York Unive rsity Centre for Public Law and Public Policy, 1991 ) at 5.

19 See R. Gibb ons, "W estern C anadian Nationalism in Transition" (1996), 7 Constitutional Forum 52; $\mathrm{P}$. McCormick, E. Manning, G. Gibson, Regional Representation: The Canadian Partnership (Calgary: Canada W est Founda tion, 1981).

\section{CONCLUSION}

Canada is the second largest country in the world, and its very dimensions are an integral part of its character and culture. Creating an upper chamber whose defining principle is representation by territory would recognize the importance of land and its function in defining our varied and sometimes conflicting interests. It would be a logical, convenient and distinctly Canadian solution to a problem with which the country has been occupied for too long.

\section{Bruce Pardy}

Faculty of Law, Victoria University of Wellington. 